\title{
Genes predisposing to type 1 diabetes mellitus and pathophysiology: a narrative review
}

Tajudeen Yahaya, ${ }^{1}$ Titilola Salisu ${ }^{2}$

pISSN: 0853-1773 - elSSN: 2252-8083 https://doi.org/10.13181/mji.rev.203732 Med J Indones. 2020;29:100-9

Received: April 24, 2019

Accepted: January 23, 2020

Authors' affiliations:

'Department of Biology, Faculty of Science, Federal University Birnin Kebbi, Kebbi State, Nigeria, ${ }^{2}$ Department of Zoology and Environmental Biology, Olabisi Onabanjo University Ago-Iwoye, Ogun State, Nigeria

\section{Corresponding author:}

Tajudeen Yahaya

Department of Biology, Faculty of

Science, Federal University Birnin Kebbi, Kebbi State, Nigeria

Tel/Fax: +234-8033550788/

$+234-8098233774$

E-mail: yahayatajudeen@gmail.com/ yahaya.tajudeen@fubk.edu.ng

\begin{abstract}
The possibility of targeting the causal genes along with the mechanisms of pathogenically complex diseases has led to numerous studies on the genetic etiology of some diseases. In particular, studies have added more genes to the list of type 1 diabetes mellitus (T1DM) suspect genes, necessitating an update for the interest of all stakeholders. Therefore this review articulates T1DM suspect genes and their pathophysiology. Notable electronic databases, including Medline, Scopus, PubMed, and Google-Scholar were searched for relevant information. The search identified over 73 genes suspected in the pathogenesis of T1DM, with human leukocyte antigen, insulin gene, and cytotoxic T lymphocyte-associated antigen 4 accounting for most of the cases. Mutations in these genes, along with environmental factors, may produce a defective immune response in the pancreas, resulting in $\beta$-cell autoimmunity, insulin deficiency, and hyperglycemia. The mechanisms leading to these cellular reactions are gene-specific and, if targeted in diabetic individuals, may lead to improved treatment. Medical practitioners are advised to formulate treatment procedures that target these genes in patients with T1DM.
\end{abstract}

KEYWORDS autoimmunity, hyperglycemia, insulin, pancreas, type 1 diabetes mellitus
Diabetes mellitus (DM) begins when hyperglycemia occurs. A hormone synthesized by the pancreatic $\beta$-cells, known as insulin, regulates blood glucose by transporting it from the bloodstream into the cells where it is metabolized. Another hormone produced by the pancreatic a-cells, known as glucagon, also assists the body in the blood glucose regulation process. In most cases, type 1 diabetes mellitus (T1DM) occurs when the immune system, which normally attacks only foreign antigens, faultly destroys the $\beta$-cells. Consequently, the pancreas stops making insulin, leading to the retention of glucose in the blood. ${ }^{1}$ Some people develop a condition known as secondary DM, which is like T1DM, but the immune system does not destroy the $\beta$-cells. ${ }^{2}$ Instead, the cells are removed by certain stimuli in the pancreas, as indicated by histopathological changes. ${ }^{2}$ T1DM was previously named juvenile DM but was renamed because adults can also develop the disease. Moreover, T1DM is not the only form of DM that affects children and young adults. Particularly, type 2 diabetes mellitus (T2DM) is becoming increasingly prevalent among young 
individuals as more and more children are becoming obese and overweight nowadays. ${ }^{3}$ Maturity-onset diabetes of the young and neonatal diabetes mellitus are other forms of DM that mainly affect children and neonates with different clinical features from T1DM.

T1DM is the most frequent chronic illness among children, accounting for $5-10 \%$ of all DM cases. ${ }^{2}$ It is the most burdensome form of DM, with a decreased life expectancy. ${ }^{4}$ About 30 million people live with T1DM worldwide, and the prevalence is predicted to increase three-fold in the 2040s.5 Uncontrolled T1DM may cause chronic complications, including retinopathy, nephropathy, neuropathy, and vascular diseases. T1DM has a strong genetic etiology modulated by some environmental triggers that may prevent the disease if avoided before autoimmunity. The treatment involves constant insulin injections, which is expensive; thus, a better approach is necessary to stem the burden of the disease. As autoimmunity is the hallmark of T1DM, an intervention that re-programs the immune system may be a potential way to treat the disease. This observation suggests that precision medicine that targets causal genes and the pathophysiology of complicated diseases, such as DM, may provide a future management when fully understood. Hence, this review was initiated to search notable electronic databases, including Medline, Scopus, PubMed, and Google-Scholar to establish T1DM suspected genes. The result will facilitate the formulation of drugs and treatment procedures that target these genes and their mechanisms.

\section{T1DM SUSPECT GENES}

At least 18 regions in the human genome were identified as hotspots for T1DM using genome-wide linkage analysis. These regions host many genes and are labeled IDDM1-IDDM18 because T1DM was formerly called insulin-dependent DM (IDDM). ${ }^{6}$ However, improvement in biological techniques has led to a greater understanding of the genetic basis of T1DM. More precise studies have reaffirmed the roles of some previously suspected genes in T1DM pathogenesis and new ones have been discovered. Many genes have been reportedly linked with T1DM, but only those with clear mechanisms are presented in this review. Tables 1-3 show the update on T1DM candidate genes, grouped according to their mechanisms of action, which are disruption of $T$ cell regulatory activities, increased susceptibility to microbial infection, oxidative stress, cytokineinduced $\beta$-cell loss, and $\beta$-cell reconfiguration. However, more genes are being added continually.

\section{Most frequently suspected T1DM predisposing genes}

Of the genes described in Tables 1-3, mutations in the major histocompatibility complex (MHC), insulin gene (INS), cytotoxic T lymphocyte-associated protein 4 (CTLA4), protein tyrosine phosphatase, non-receptor type 2 (PTPN2), and protein tyrosine phosphatase, non-receptor type 22 (PTPN22) genes account for most of the T1DM cases. Detailed information on the diabetogenic activities of these genes is given below.

Table 1. T1DM suspect genes that disrupt $\mathrm{T}$ cell immune regulatory activities and increase susceptibility to microbial infection

\begin{tabular}{|c|c|c|c|}
\hline Gene & Full name & Locus & Mechanism \\
\hline CTLA4 & $\begin{array}{c}\text { Cytotoxic } \\
\text { T-lymphocyte } \\
\text { associated protein } 4\end{array}$ & $2 q 33.2$ & $\begin{array}{l}\text { Causes massive lymphocyte proliferation, resulting in overexpression of T cells, } \\
\text { which attack self-antigens, leading to } \beta \text {-cell apoptosis. }{ }^{7}\end{array}$ \\
\hline FOXP3 & Forkhead box P3 & Xp11.23 & $\begin{array}{l}\text { Disrupts the activities of many endocrine glands, affecting the immune regulatory } \\
\text { T cells and setting of autoimmunity. }{ }^{8}\end{array}$ \\
\hline$P R K C Q$ & $\begin{array}{l}\text { Protein kinase } \mathrm{C} \\
\text { theta }\end{array}$ & 10p15.1 & Loss of T cell signaling, leading to a compromised immune system. ${ }^{9}$ \\
\hline IL7R & $\begin{array}{l}\text { Interleukin } 7 \\
\text { receptor }\end{array}$ & $5 p 13.2$ & Causes a compromised immune system, characterized by depletion of T cells. ${ }^{10}$ \\
\hline IL2 & Interleukin 2 & $4 q 27$ & Causes functional loss of T cell (Treg) regulation, resulting in autoimmunity. ${ }^{11}$ \\
\hline ITGB7 & $\begin{array}{l}\text { Integrin subunit } \\
\quad \text { beta } 7\end{array}$ & $12 q 13.13$ & It disrupts the activities of T cells in the pancreas, resulting in autoimmunity. ${ }^{12}$ \\
\hline SH2B3 & $\begin{array}{l}\text { SH2B adaptor } \\
\text { protein } 3\end{array}$ & $12 q 24.13$ & Increases self-reactive T lymphocyte proliferation. ${ }^{13}$ \\
\hline RASGRP1 & $\begin{array}{l}\text { RAS guanyl releasing } \\
\text { protein } 1\end{array}$ & $15 q 14$ & $\begin{array}{l}\text { Reduced expression results in splenomegaly and autoantibodies, while complete } \\
\text { deletion decreases T cell development in the thymus. }{ }^{14}\end{array}$ \\
\hline
\end{tabular}


Table 1. (continued)

\begin{tabular}{|c|c|c|c|}
\hline Gene & Full name & Locus & Mechanism \\
\hline CD28 & CD28 molecule & $2 q 33.2$ & $\begin{array}{l}\text { Mediates loss of function of regulatory T cells, leading to autoimmunity of the } \\
\text { pancreatic } \beta \text {-cells. }{ }^{15}\end{array}$ \\
\hline ICOS & $\begin{array}{l}\text { Inducible T cell } \\
\text { costimulator }\end{array}$ & $2 q 33.2$ & It suppresses insulin-specific regulatory T cells. ${ }^{16}$ \\
\hline ART2/RT6 & $\begin{array}{l}\text { Antisense to } \\
\text { ribosomal RNA } \\
\text { transcript protein } 2\end{array}$ & $11 \mathrm{p} 15.4$ & $\begin{array}{l}\text { Causes insulitis in which the islets are massively infiltrated by macrophages and } \\
\text { T cells. }{ }^{17}\end{array}$ \\
\hline UBASH3A & $\begin{array}{l}\text { Ubiquitin associated } \\
\text { and } \mathrm{SH} 3 \text { domain } \\
\text { containing } \mathrm{A}\end{array}$ & $21 q 22.3$ & $\begin{array}{l}\text { Increases UBASH3A expression in CD4+ T cells, disrupting NF-KB signaling, which } \\
\text { in turn represses IL2 gene expression. }{ }^{18}\end{array}$ \\
\hline SUMO4 & $\begin{array}{l}\text { Small ubiquitin-like } \\
\text { modifier } 4\end{array}$ & $6 q 25.1$ & $\begin{array}{l}\text { Reduces sumoylation capacity, causing overexpression of NF-KB and IL12B, and } \\
\text { leading to } \beta \text {-cell autoimmunity. }{ }^{19}\end{array}$ \\
\hline MHC & $\begin{array}{l}\text { Major } \\
\text { histocompatibility } \\
\text { complex }\end{array}$ & $6 p 21.31$ & Causes loss of T cell signaling, leading to autoimmunity of the pancreatic $\beta$-cells. ${ }^{20}$ \\
\hline NRP1 & Neuropilin 1 & 10p11.22 & $\begin{array}{l}\text { Causes defects in Treg phenotype decreasing its signaling activities, culminating } \\
\text { in autoimmunity of the } \beta \text {-cells. }{ }^{21}\end{array}$ \\
\hline MIF & $\begin{array}{l}\text { Macrophage } \\
\text { migration inhibitory } \\
\text { factor }\end{array}$ & $22 q 11.23$ & $\begin{array}{l}\text { Causes high MIF concentrations in the blood, resulting in dysfunctional pancreatic } \\
\text { islets. Also causes loss of function of immune cells, such as macrophages and T } \\
\text { cells, increasing the risk of } \beta \text {-cell autoimmunity. }{ }^{22}\end{array}$ \\
\hline CD226 & $\begin{array}{c}\text { Cluster of } \\
\text { differentiation } 226\end{array}$ & $18 q 22.2$ & $\begin{array}{l}\text { Increases the frequency of GAD autoantibody and lowers C-peptide levels, } \\
\text { accelerating } \beta \text {-cell destruction. }{ }^{23}\end{array}$ \\
\hline IL6 & Interleukin 6 & $7 p 15.3$ & $\begin{array}{l}\text { Impairs immune response, leading to } \beta \text {-cell autoimmunity, it also leads to } \\
\text { impaired fat breakdown in tissues such as muscle cells. }{ }^{24}\end{array}$ \\
\hline IL10 & Interleukin 10 & $1 q 32.1$ & $\begin{array}{l}\text { It negatively regulates a } \mathrm{T} \text { cell called Th17, setting up autoimmunity of the } \\
\text { pancreatic } \beta \text {-cells. }{ }^{25}\end{array}$ \\
\hline IL12B & Interleukin 12B & $5 q 31-33$ & $\begin{array}{l}\text { It negatively regulates a T cell called Th17, setting up autoimmunity of the } \\
\text { pancreatic } \beta \text {-cells. }{ }^{26}\end{array}$ \\
\hline PTPN22 & $\begin{array}{l}\text { Protein tyrosine } \\
\text { phosphatase, non- } \\
\text { receptor type } 22\end{array}$ & $1 \mathrm{p} 13.2$ & $\begin{array}{l}\text { Disrupts elimination of autoreactive } \beta \text {-cells, and upregulates certain } \beta \text {-cell genes, } \\
\text { leading to } \beta \text {-cell death. }{ }^{27}\end{array}$ \\
\hline$V D R$ & Vitamin D receptor & $12 q 13.11$ & It causes dysfunctional immune mechanism, leading to autoimmunity. ${ }^{28}$ \\
\hline IL26 & Interleukin 26 & $12 q 15$ & $\begin{array}{l}\text { Disrupts sensing of bacteria by the defense mechanism, }{ }^{29} \text { resulting in the attack } \\
\text { of } \beta \text {-cells. }\end{array}$ \\
\hline TAGAP & $\begin{array}{l}\text { T cell activation } \\
\text { RhoGTPase } \\
\text { activating protein }\end{array}$ & $6 q 25.3$ & $\begin{array}{l}\text { Causes deficiency of several important regulators of antiviral response, } \\
\text { including IFN- } \beta \text {, culminating in loss of antiviral signaling pathways, and } \beta \text {-cell } \\
\text { autoimmunity. }\end{array}$ \\
\hline TYK2 & Tyrosine kinase 2 & 19p13.2 & Represses TYK2, predisposing the body to virus attack. ${ }^{31}$ \\
\hline GAD2 & $\begin{array}{l}\text { Glutamic acid } \\
\text { decarboxylase } 2\end{array}$ & 10p12.1 & $\begin{array}{l}\text { Promotes invasion of } \beta \text {-cells by viruses, setting of autoimmunity of the } \beta \text {-cells, } \\
\text { leading to insulin deficiency. }{ }^{32}\end{array}$ \\
\hline OAS1 & $\begin{array}{l}\text { 2'-5'-oligoadenylate } \\
\text { synthetase } 1\end{array}$ & $12 q 24.13$ & Predisposes to viral infection, setting in $\beta$-cell autoimmunity. ${ }^{33}$ \\
\hline IFIH1 & $\begin{array}{l}\text { Interferon induced } \\
\text { with helicase } C \\
\text { domain } 1\end{array}$ & $2 q 24.2$ & $\begin{array}{l}\text { Produces abnormal antiviral immune response, increasing the risk of } \\
\text { autoimmunity. }{ }^{34}\end{array}$ \\
\hline FUT2 & Fucosyltransferase 2 & $19 q 13.33$ & Alters the gut microbiome, increasing the risk of autoimmunity of the $\beta$-cells. ${ }^{35}$ \\
\hline
\end{tabular}

T1DM=type 1 diabetes mellitus; Treg=regulatory T cell; NF-kB=nuclear factor kappa B; Th17=T helper 17 cells; IFN- $\beta=$ interferon beta 
Table 2. T1DM suspect genes that mediate oxidative stress and cytokine-induced $\beta$-cell loss

\begin{tabular}{|c|c|c|c|}
\hline Gene & Full name & Locus & Mechanism \\
\hline SIRT1 & Sirtuin 1 & $10 q 21.3$ & $\begin{array}{l}\text { Produces defective sirtuin, inducing cytokines to attack wrong cells, } \\
\text { particularly } \beta \text {-cells. }{ }^{36}\end{array}$ \\
\hline ERBB3 & $\begin{array}{l}\text { Erb-B2 receptor tyrosine } \\
\quad \text { kinase } 3\end{array}$ & $12 q 13.2$ & $\begin{array}{l}\text { Disrupts antigen presentation, causing cytokine-induced } \beta \text {-cell } \\
\text { apoptosis. }^{37}\end{array}$ \\
\hline PTPN2 & $\begin{array}{l}\text { Protein tyrosine } \\
\text { phosphatase, non- } \\
\text { receptor type } 2\end{array}$ & $18 p 11.21$ & $\begin{array}{l}\text { Produces cytokine, which induces destruction of } \beta \text {-cells and } \\
\text { mitochondrial apoptotic pathway, disrupting glucose metabolism. }{ }^{38}\end{array}$ \\
\hline $\mathrm{BACH} 2$ & $\begin{array}{l}\text { BTB domain and CNC } \\
\text { homolog } 2\end{array}$ & $6 q 15$ & $\begin{array}{l}\text { Decreases PTPN2 expression, promoting pro-inflammatory cytokine- } \\
\text { induced } \beta \text {-cell apoptosis. }{ }^{39}\end{array}$ \\
\hline IL21 & Interleukin 21 & $4 q 27$ & Causes inflammatory infiltration of pancreatic islets. ${ }^{40}$ \\
\hline CENPW/C6orf173 & Centromere protein $\mathrm{W}$ & $6 q 22.32$ & Contributes to the generation of autoantibodies in the islets. ${ }^{41}$ \\
\hline AFF3 & $\begin{array}{l}\text { AF4/FMR2 family } \\
\text { member } 3\end{array}$ & $2 q 11.2$ & $\begin{array}{l}\text { Alters the expression of monocytes as well as macrophages and dendritic } \\
\text { cells, causing gradual destruction of } \beta \text {-cells. }{ }^{42}\end{array}$ \\
\hline TNFAIP3 & $\begin{array}{l}\text { Tumor necrosis factor } \\
\text { alpha induced protein } 3\end{array}$ & $6 q 23.3$ & $\begin{array}{l}\text { Loss of functional regulation of } \beta \text {-cell apoptosis, leading to poor glycemic } \\
\text { control. }{ }^{43}\end{array}$ \\
\hline$R N L S$ & $\begin{array}{l}\text { Renalase, FAD dependent } \\
\text { amine oxidase }\end{array}$ & $10 q 23.31$ & $\begin{array}{l}\text { Alters the expression of monocytes as well as macrophages and dendritic } \\
\text { cells, causing gradual destruction of } \beta \text {-cells. }{ }^{44}\end{array}$ \\
\hline GPR183/EBI2 & $\begin{array}{l}\text { G protein-coupled } \\
\text { receptor } 183\end{array}$ & $13 q 32.3$ & $\begin{array}{l}\text { Changes the expression of monocytes as well as macrophages and } \\
\text { dendritic cells, causing gradual destruction of } \beta \text {-cells. }{ }^{42}\end{array}$ \\
\hline CLECL1 & C-type lectin like 1 & $12 \mathrm{p} 13.31$ & $\begin{array}{l}\text { Alters the expression of monocytes as well as macrophages and dendritic } \\
\text { cells, causing gradual destruction of } \beta \text {-cells. }{ }^{42}\end{array}$ \\
\hline DEXI & $\begin{array}{l}\text { Dexamethasone-induced } \\
\text { protein }\end{array}$ & $16 p 13.13$ & Depletes gut microbial metabolites, causing autoimmunity of $\beta$-cells. ${ }^{45}$ \\
\hline SUOX & Sulfite oxidase & $12 q 13.2$ & $\begin{array}{l}\text { Alters the expression of monocytes as well as macrophages and dendritic } \\
\text { cells, causing gradual destruction of } \beta \text {-cells. }{ }^{42}\end{array}$ \\
\hline SMARCE1 & $\begin{array}{c}\text { SWI/SNF related, } \\
\text { matrix associated, actin } \\
\text { dependent regulator of } \\
\text { chromatin, subfamily e, } \\
\text { member } 1\end{array}$ & $17 q 21.2$ & $\begin{array}{l}\text { Alters the expression of monocytes as well as macrophages and dendritic } \\
\text { cells, causing gradual destruction of } \beta \text {-cells. }{ }^{42}\end{array}$ \\
\hline FKRP & Fukutin-related protein & $19 q 13.32$ & $\begin{array}{l}\text { Alters the expression of monocytes as well as macrophages and dendritic } \\
\text { cells, causing gradual destruction of } \beta \text {-cells. }{ }^{42}\end{array}$ \\
\hline IL27 & Interleukin 27 & $16 \mathrm{p} 11.2$ & Promotes inflammations of the islet cells. ${ }^{46}$ \\
\hline SOD2 & Superoxide dismutase 2 & $6 q 25.3$ & $\begin{array}{l}\text { Enhances generation of free oxygen radical, stressing, and contributing } \\
\text { to } \beta \text {-cell death. }{ }^{6}\end{array}$ \\
\hline$B C L-2$ & $\begin{array}{l}\text { B-cell leukemia/ } \\
\text { lymphoma } 2\end{array}$ & $18 q 21.33$ & Initiates intracellular apoptotic pathway, resulting in islet cell death. ${ }^{47}$ \\
\hline FAS/CD95 & $\begin{array}{l}\text { Fas cell surface death } \\
\text { receptor }\end{array}$ & $10 q 23.31$ & $\begin{array}{l}\text { Initiates glucose-induced DNA fragmentation, resulting in pancreatic } \\
\text { islet apoptosis. }{ }^{48}\end{array}$ \\
\hline$I L-1 A$ & Interleukin 1 alpha & $2 q 14.1$ & $\begin{array}{l}\text { Initiates glucose-induced DNA fragmentation, resulting in pancreatic } \\
\text { islet apoptosis. }{ }^{48}\end{array}$ \\
\hline APOC3 & Apolipoprotein C3 & $11 q 23.3$ & Causes influx of $\mathrm{Ca}^{2+}$ into the $\beta$-cells, destroying the cells. ${ }^{49}$ \\
\hline$B A D$ & $\begin{array}{l}\mathrm{BCL2} \text {-associated agonist } \\
\text { of cell death }\end{array}$ & $11 q 13.1$ & Loss of control of programmed cell death. ${ }^{50}$ \\
\hline NOS2 & Nitric oxide synthase 2 & $17 q 11.2$ & $\begin{array}{l}\text { Produces nitric oxide, inducing apoptosis in several cells, including } \\
\beta \text {-cells. }{ }^{51}\end{array}$ \\
\hline
\end{tabular}


Table 2. (continued)

\begin{tabular}{|c|c|c|c|}
\hline Gene & Full name & Locus & Mechanism \\
\hline PTEN & $\begin{array}{l}\text { Phosphatase and tensin } \\
\text { homolog }\end{array}$ & $10 q 23.31$ & Causes gradual destruction of $\beta$-cells. ${ }^{52}$ \\
\hline CASP7 & Caspase 7 & $10 q 25.3$ & Causes gradual destruction of $\beta$-cells. ${ }^{53}$ \\
\hline HIP14 & $\begin{array}{l}\text { Huntingtin-interacting } \\
\text { protein } 14\end{array}$ & & Accelerates apoptotic cell death. ${ }^{54}$ \\
\hline STAT4 & $\begin{array}{l}\text { Signal transducer and } \\
\text { activator of transcription } 4\end{array}$ & $2 q 32.2$ & $\begin{array}{l}\text { Its activation causes cytokine-induced islet apoptosis, resulting in } \beta \text {-cell } \\
\text { dysfunction. }{ }^{55}\end{array}$ \\
\hline CCR5 & C-C chemokine receptor 5 & $3 p 21.31$ & $\begin{array}{l}\text { Mediates infiltration of the pancreatic islets by abnormal blood cells, } \\
\text { culminating in the gradual destruction of } \beta \text {-cells. } .^{56}\end{array}$ \\
\hline ITPR3 & $\begin{array}{l}\text { Inositol } \\
\text { 1,4,5-trisphosphate } \\
\text { receptor type } 3\end{array}$ & $6 p 21.31$ & $\begin{array}{l}\text { Causes dysregulated calcium transport, leading to loss of insulin } \\
\text { secretion function of the } \beta \text {-cells, culminating in high blood glucose and } \\
\text { high HbA1c beyond healthy levels. }{ }^{57}\end{array}$ \\
\hline
\end{tabular}

T1DM=type 1 diabetes mellitus; HbA1c=hemoglobin A1C

Table 3. T1DM suspect genes that reconfigure $\beta$-cell morphology and identity

\begin{tabular}{|c|c|c|c|}
\hline Gene & Full name & Locus & Mechanism \\
\hline INS & Insulin gene & $11 \mathrm{p} 15.5$ & $\begin{array}{l}\text { Breakage of phenylalanine amino acid, hampering maturation of } \\
\text { preproinsulin to insulin. }{ }^{58}\end{array}$ \\
\hline HNFIA & $\begin{array}{l}\text { Hepatocyte nuclear } \\
\text { factor-1 alpha }\end{array}$ & $12 q 2431$ & $\begin{array}{l}\text { Disruption of insulin biosynthesis, leading to hyperglycemia and osmotic } \\
\text { diuresis. }^{59}\end{array}$ \\
\hline$S L C 2 A 2$ & $\begin{array}{l}\text { Solute carrier family } \\
\qquad 2 \text { member } 2\end{array}$ & $3 q 26.2$ & Fanconi-Bickel syndrome, causing lack of insulin in utero..$^{60}$ \\
\hline Amylin & $\begin{array}{l}\text { Islet amyloid } \\
\text { polypeptide }\end{array}$ & $12 \mathrm{p} 12.1$ & $\begin{array}{l}\text { Causes over secretion of amylin, which aggregate in the pancreatic } \\
\beta \text {-cells, causing } \beta \text {-cell death and impairing insulin secretion. }{ }^{11}\end{array}$ \\
\hline NKX2.2 & NK2 homeobox 2 & 20p11.22 & Causes $\beta$-cell reconfiguration, leading to loss of insulin synthesis. ${ }^{62}$ \\
\hline GLIS3 & GLI-similar 3 & $9 p 24.2$ & Suppresses insulin gene expression, causing pancreatic $\beta$-cell death. ${ }^{63}$ \\
\hline NEUROD1 & $\begin{array}{c}\text { Neuronal } \\
\text { differentiation } 1\end{array}$ & $2 q 32$ & $\begin{array}{l}\text { Affects } \beta \text {-cell morphogenesis and differentiation, promoting } \beta \text {-cell } \\
\text { apoptosis. }{ }^{64}\end{array}$ \\
\hline CTSH & Cathepsin H & $15 q 25.1$ & Progressively reduces the survival of $\beta$-cells. ${ }^{65}$ \\
\hline DLL1 & $\begin{array}{l}\text { Delta-like1- } \\
\text { Drosophila }\end{array}$ & $6 q 27$ & Hampers $\beta$-cell differentiation and maturation. ${ }^{66}$ \\
\hline ORMDL3 GSDMB & Orosomucoid like 3 & $17 q 12$ & $\begin{array}{l}\text { Reduces sulfatide levels in the pancreatic islet, causing unregulated } \\
\text { proinsulin folding as well as apoptosis. }{ }^{67}\end{array}$ \\
\hline FADD & $\begin{array}{l}\text { Fas-associated death } \\
\text { domain }\end{array}$ & $11 q 13.3$ & Disrupts transcription of pancreatic cells. ${ }^{6}$ \\
\hline CDKN1B/p27KIP1 & $\begin{array}{l}\text { Cyclin-dependent } \\
\text { kinase inhibitor } 1 \mathrm{~B}\end{array}$ & $12 \mathrm{p} 13.1$ & Causes loss of $\beta$-cell mass, and poor glucose metabolism. ${ }^{68}$ \\
\hline IRS2 & $\begin{array}{l}\text { Insulin receptor } \\
\text { substrate } 2\end{array}$ & $13 q 34$ & Reduces $\beta$-cell mass. ${ }^{69}$ \\
\hline IL2RA/CD25 & $\begin{array}{l}\text { Interleukin } 2 \\
\text { receptor alpha }\end{array}$ & $10 p 15.1$ & $\begin{array}{l}\text { Causes inflammatory bowel disease, } \beta \text {-cell enlargement, leading to } \\
\text { autoimmunity. }{ }^{70}\end{array}$ \\
\hline
\end{tabular}

T1DM=type 1 diabetes mellitus 


\section{MHC}

MHC is about a 4 megabases genetic section on chromosome 6 ( 6 p21) containing immune recognition genes. ${ }^{20}$ Many versions of MHC occur among animal species. ${ }^{20}$ In humans, it is called the HLA complex and contains over 200 genes grouped into class I, II, and III. ${ }^{20}$ Class I has three major genes, named HLA-A, HLA-B, and HLA-C. ${ }^{71}$ The proteins encoded by these genes are expressed on the surface of most nucleated cells, where they bind to protein fragments (peptides) exported from within the cell. ${ }^{71}$ Class I proteins present these peptides to the immune system, and apoptosis is induced if the peptides are recognized as foreign, such as viral or bacterial peptides. ${ }^{71}$ Human $\mathrm{MHC}$ class II has six main genes, including HLA-DPA1, HLA-DPB1, HLA-DQA1, HLA-DQB1, HLA-DRA, and HLA-DRB1. ${ }^{71}$ The proteins produced by these genes are expressed mainly on the surface of certain immune system cells, including B lymphocytes, dendritic cells, macrophages, and activated T lymphocytes. ${ }^{71}$ Class II proteins display peptides to the immune system. ${ }^{71}$

HLA class I and II genes are highly polymorphic, and inheritance of certain variants may predispose the affected individual to an autoimmune disorder. Certain HLA class II alleles or combinations of alleles (haplotypes) significantly increase the risk of T1DM, while others confer reduced or protective effects. ${ }^{72}$ For example, most individuals with T1DM are carriers of either HLA-DR3, DQB1*0201 (also called $\mathrm{DR}_{3}-\mathrm{DQ} 2$ ), or $\mathrm{DR} 4-\mathrm{DQB} 1{ }^{* 0302}$ (otherwise known as DR4-DQ8). ${ }^{72}$ Also, inheriting the HLA haplotype DRB1*0302-DQA 1 *0301, particularly when combined with DRB1*0201-DQA1*0501, increases genetic predisposition to T1DM as much as 20-fold. ${ }^{72}$ In contrast, the haplotype $\mathrm{DRB}_{1}$ *0602-DQA 1 *0102 rarely predisposes to T1DM, ${ }^{72}$ while the haplotype HLA-DQ6 (HLA-DQA1*0102-DQB1*0602) is protective. ${ }^{6}$

\section{INS gene}

INS gene was the second gene linked with T1DM and accounts for about $10 \%$ of T1DM cases..$^{34}$ It encodes the precursor to insulin, which assists the body to store energy for later use. ${ }^{73}$ For example, insulin helps the body store glucose as glycogen or fat rather than metabolizing it. Insulin has two separate polypeptide chains, chains A and B, and are connected by disulfide bonds. ${ }^{73}$ Unlike some proteins that are synthesized by several genes, insulin is synthesized by the INS gene only. Some animals, such as rats and mice, have two insulin genes but humans only have one. To produce insulin, the INS gene secretes an inactive insulin precursor called preproinsulin, which is converted to another inactive substance called proinsulin by removal of a signaling peptide..$^{73}$ Insulin is finally produced from proinsulin by removal of the $C$-peptide that binds chains $A$ and $B$ together. ${ }^{73}$ However, mutations in the INS gene may disrupt the insulin biosynthetic network, causing some diseases. A point mutation in the INS gene known as $\mathrm{C} 96 \mathrm{Y}$ synthesizes mutant proinsulin, resulting in endoplasmic reticulum (ER) stress, which progressively causes death of $\beta$-cells and T1DM. ${ }^{74}$ Several other point mutations have also been reported in individuals and animals with T1DM.

The promoter region of the INS gene is highly polymorphic and contains several variable numbers of tandem repeats (VNTRs), grouped into classes I, II, and III. ${ }^{20}$ VNTR I contains 26-63 repeats, VNTR II has 80 repeats, and VNTR III has $140-210$ repeats. Among Caucasians, VNTR I is highly prevalent, VNTR III is moderately prevalent, while VNTR II is rare. VNTR I homozygotes often develop T1DM than VNTR III, while VNTR II confers a protective effect. ${ }^{20} \mathrm{~A}$ polymorphism in the promoter region of the INS gene determines the regulatory activities of the transcription factor autoimmune regulator on thymic expression of insulin. The VNTR I allele reduces tolerance to insulin and its precursors, repressing insulin transcription and predisposing the individual to T1DM. ${ }^{20}$ The VNTR II allele promotes the expression of insulin mRNA in the thymus. ${ }^{20}$

\section{CTLA4 gene}

CTLA4 gene is expressed on the surface of activated $T$ cells, where it attenuates the immune response by binding to ligands $\mathrm{CD} 80$ or CD86 expressed on the surface of antigen-presenting cells. ${ }^{75}$ The CTLA4-CD80/CD86 complex represses the IL-2 receptor (CD25), reducing IL-2 synthesis or triggering cell death in already activated cells. ${ }^{75}$ CTLA4 protein also mediates the suppressive activity of $C_{4}+C D 25+T$ regulatory cells. ${ }^{75}$ The expression of CTLA4 in activated $\mathrm{T}$ lymphocytes shows that it maintains immune function by preventing the inflammatory response and autoimmunity. ${ }^{74}$ Thus, CTLA4 plays a negative regulatory role in immune function by preventing the overexpression of $\mathrm{T}$ cells. Functional impairment in the CTLA4 gene may cause overexpression of T cells, causing it to attack self-antigens. Deletion of the 
CTLA4 gene in mice leads to massive proliferation of lymphocytes, resulting in autoimmunity and death. ${ }^{74}$

Several autoimmune disorders have been associated with functional loss or impairment of the CTLA4 gene. A single nucleotide polymorphism (SNP) $+6230 \mathrm{G}>\mathrm{A}$ characterized by splicing of the gene or altered mRNA is linked with an increased risk for T1DM..$^{75}$ The promoter region of the CTLA4 gene is polymorphic and a particular SNP $-319 C>T$, which reduces the transcription of the gene, is related to a high risk of T1DM. ${ }^{75}$ SNP involving an A-to-G substitution at nucleotide 49 in exon 1 (G49A), causing an amino acid substitution (Thr17Ala) has also been reported in patients with T1DM. ${ }^{75}$ The predisposing Ala17 allele is partially glycosylated in the ER, resulting in retrograde transport of some molecules into the cytoplasm for lysis, ${ }^{75}$ leading to less CTLA4 (Ala17) at the cell surface, which may be responsible for loss of function of the CTLA4 gene expressed by individuals with the $+49 \mathrm{C}$ allele. ${ }^{75}$ Thus, the G49A allele reduces the negative regulatory role of CTLA4 and predisposes to TIDM, compared with the $49 \mathrm{G} / \mathrm{G}$ alleles, which confers protection. ${ }^{74}$

\section{PTPN22 and PTPN2 genes}

PTPN22 and PTPN2 genes both code for protein tyrosine phosphatase (PTP) signaling molecules that modulate and regulate several biological processes, including cell growth, survival, and differentiation. ${ }^{76}$ PTPs are important regulators of signaling transduction, as they relay signals from the cell into the nucleus. ${ }^{76}$ Besides cell growth and differentiation, these molecules initiate cell signaling for $T$ cell immune regulatory activities. ${ }^{76}$ PTPs are so important in immune regulation that they are more expressed on immune cells than other body tissues. ${ }^{76} \mathrm{~A}$ deficiency of PTP in mice distinctively upregulates immune status with severe abnormalities in hematopoiesis, suggesting that PTPs play an important role in maintaining a balanced immune system. ${ }^{76} \mathrm{~A}$ deficiency in these signaling molecules because of inactivation or loss of PTPN2 or PTPN22 leads to decreased suppression of the inflammatory response resulting from reduced negative regulation. ${ }^{76}$

PTPN22 is the fourth gene linked with T1DM in which the rs2476601 SNP disrupts PTP intracellular signaling, leading to loss of negative immune regulation. ${ }^{75}$ The SNP causes a single substitution of arginine for tryptophan in the encoded protein (R620W), leading to a decrease in T cell and B cell receptor signaling. ${ }^{77}$ This may disrupt tolerance in both $T$ and $B$ cells, ultimately resulting in diabetes-specific autoimmunity. ${ }^{77}$ The autoimmunity induced by this SNP is characterized by a preponderance of autoreactive $B$ cells and autoantibodies, both of which are biomarkers for the onset and progression of T1DM. ${ }^{77}$ The mechanism for the role of the PTPN2 gene in the pathogenesis of T1DM is complex, consequent to expression in many cells, but is suspected to involve destruction of pancreatic $\beta$-cells. Functional loss of the PTPN2 gene may also hamper negative regulation of the apoptotic pathway, leading to overexpression of T cells. Repression of the PTPN2 gene impairs insulin production by $\beta$-cells in diabetic mice. In normal individuals, PTPN2 gene blocks insulin signaling by dephosphorylation of its $\beta$-chain receptor with the assistance of PTP1B phosphatase. This, in turn, controls gluconeogenesis in the liver by suppressing STAT3 signaling and decreasing glucose production. Mutant PTPN2 induces mitochondrial apoptotic pathways, resulting in $\beta$-cell apoptosis and unbalanced glucose metabolism. A version of PTPN2 (rs1893217) has been reported to upregulate $T$ cell receptor signaling in mice, causing impaired self-antigen recognition and $\beta$-cells destruction consequent to the loss of negative regulation. ${ }^{38}$

\section{Application of autoantibodies and proteins of T1DM suspect genes as biomarkers}

No guidelines have been established for T1DM genetic testing as it is done in DM with monogenetic etiology. This is partly because several genes may interact to cause T1DM and testing for individual genes may not be cost-effective. Also, genetic susceptibility alone may not fully explain the etiology of the disease as environmental triggers, such as diet, infection, and pollutants may play a role in onset of the disease. Nevertheless, the Immunology of Diabetes Society has suggested that certain autoantibodies in individuals with a family history of T1DN may predict the likelihood of the disease. These autoantibodies include islet cell antibodies, insulin autoantibodies, the GAD autoantibody, and the protein tyrosine phosphatase IA-2/ICA512. ${ }^{78}$ Tables 1 and 2 present some genes that produce these autoantibodies. The $\beta$-cell function determined by the first-phase insulin response in the intravenous glucose tolerance test can also predict onset of the disease. ${ }^{78}$ The genes whose mutations or variants affect $\beta$-cell differentiation and 
morphology, resulting in loss or reduced functions, are shown in Table 3. The levels of the proteins produced by genes predisposing to enteroviruses, such as $B$ coxsackieviruses, are also a good biomarker of the disease. Notable among these genes are the HLA, PPTN22, PPTN2, and CTLA4 genes discussed earlier. Abnormal levels of the MHC and CTLA4 proteins could indicate enteroviral induced autoimmunity in T1DM, prompting a therapeutic measure. Viral infection may also raise the concentration of interferons in islet $\beta$-cells, which overexpress $\mathrm{MHC}$, resulting in increased susceptibility to cytotoxic $\mathrm{CD} 8+\mathrm{T}$ cell recognition and destruction. ${ }^{79}$ Other genes listed earlier whose concentrations are sensitive to viral infections include ERBB3, PRKCQ, IL7R, IL2, TAGAP, IL26, IL10, IL12B, and OAS1 (Table 1).

In summary, the reviewed articles indicate that mutations in or variants of certain genes may induce autoimmunity in $\beta$-cells by compromising the immune system, predisposing the carrier to T1DM. Many T1DM predisposing genes have been identified; however, individual genes alone cannot cause the disease. These genes interact with each other, suppressing or overexpressing the functions of one another and may induce DM along with environmental stimuli. These genes initiate DM through different mechanisms, which may result in improved treatment. Healthcare providers are advised to formulate treatment plans that target these genes and mechanisms rather than the current generalized treatment procedure.

\section{Conflict of Interest}

The authors affirm no conflict of interest in this study.

\section{Acknowledgment}

None.

\section{Funding Sources}

None.

\section{REFERENCES}

1. National Institute of Diabetes and Digestive and Kidney Diseases. Type 1 diabetes: what is type 1 diabetes? [Internet]. 2017 [cited $2018 \mathrm{Jul}$ 18]. Available from: https://www.niddk.nih. gov/health-information/diabetes/overview/what-is-diabetes/ type-1-diabetes.

2. WebMD. Type 1 diabetes [Internet]. EndocrineWeb. 2018 [cited 2018 Oct 28]. Available from: https://www.webmd.com/ diabetes/type-1-diabetes\#1.

3. Norman J. What is type 1 diabetes [Internet]. EndocrineWeb; 2018 [cited 2018 Oct 3]. Available from: https://www. endocrineweb.com/conditions/type-1-diabetes/type-1-diabetes.

4. Bennington-Castro J. What Is type 1 diabetes? [Internet]. Everyday Health. 2015. [cited 2018 Sep 3]. Available from https:// www.everydayhealth.com/type-1-diabetes/guide/.

5. Dabelea D, Mayer-Davis EJ, Saydah S, Imperatore G, Linder $B$, Divers J, et al. Prevalence of type 1 and type 2 diabetes among children and adolescents from 2001 to 2009. JAMA. 2014;311(17):1778-86.

6. Pociot F, McDermott MF. Genetics of type 1 diabetes mellitus. Genes Immun. 2002;3(5):235-49.

7. Lohmueller KE, Pearce CL, Pike M, Lander ES, Hirschhorn JN. Meta-analysis of genetic association studies supports a contribution of common variants to susceptibility to common disease. Nat Genet. 2003;33(2):177-82.

8. Bacchetta R, Maccari ME. Type 1 diabetes mellitus in monogenic autoimmune diseases. In: Barbetti F, Ghizzoni L, Guaraldi F, editors. Diabetes associated with single gene defects and chromosomal abnormalities. vol 25th. Basel: Karger; 2017. p. 78-90.

9. Baxter AG, Jordan MA. From markers to molecular mechanisms: type 1 diabetes in the post-GWAS era. Rev Diabet Stud. 2012;9(4):201-23.

10. Giliani S, Mori L, de Saint Basile G, Le Deist F, Rodriguez-Perez C, Forino C, et al. Interleukin-7 receptor alpha (IL-7Ralpha) deficiency: cellular and molecular bases. analysis of clinical, immunological, and molecular features in 16 novel patients. Immunol Rev. 2005;203:110-26.

11. Hulme MA, Wasserfall $\mathrm{CH}$, Atkinson MA, Brusko TM. Central role for interleukin-2 in type 1 diabetes. Diabetes. 2012;61(1):14-22.

12. del-Rio ML, Bernhardt G, Rodriguez-Barbosa Jl, Förster R. Development and functional specialization of CD103+ dendritic cells. Immunol Rev. 2010;234(1):268-81.

13. Hotta-Iwamura C, Tarbell KV. Type 1 diabetes genetic susceptibility and dendritic cell function: potential targets for treatment. J Leukoc Biol. 2016;100(1):65-80.

14. Daley SR, Coakley KM, Hu DY, Randall KL, Jenne CN, Limnander $A$, et al. Rasgrp1 mutation increases naïve T-cell CD44 expression and drives mTOR-dependent accumulation of $\mathrm{Helios}^{+} \mathrm{T}$ cells and autoantibodies. Elife. 2013;2:e01020.

15. Boehm BO, Bluestone JA. Differential roles of costimulatory signaling pathways in type 1 diabetes mellitus. Rev Diabet Stud. 2004;1(4):156-64.

16. Tiittanen M, Huupponen JT, Knip M, Vaarala O. Insulin treatment in patients with type 1 diabetes induces upregulation of regulatory T-cell markers in peripheral blood mononuclear cells stimulated with insulin in vitro. Diabetes. 2006;55(12):3446-54.

17. Jiang Z, Handler ES, Rossini AA, Woda BA. Immunopathology of diabetes in the RT6-depleted diabetes-resistant BB/Wor rat. Am J Pathol. 1990;137(4):767-77.

18. Ge Y, Paisie TK, Newman JRB, Mclntyre LM, Concannon P. UBASH3A mediates risk for type 1 diabetes through inhibition of T-cell receptor-induced NF-KB signaling. Diabetes. 2017;66(7):2033-43.

19. Fung EY, Smyth DJ, Howson JM, Cooper JD, Walker NM, Stevens $\mathrm{H}$, et al. Analysis of 17 autoimmune disease-associated variants in type 1 diabetes identifies 6q23/TNFAIP3 as a susceptibility locus. Genes Immun. 2009;10(2):188-91.

20. Noble JA, Erlich HA. Genetics of type 1 diabetes. Cold Spring Harb Perspect Med. 2012;2:a007732.

21. Visperas A, Vignali DA. Are $T_{\text {regs }}$ defective in type 1 diabetes and can we fix them? J Immunol. 2016;197(10):3762-70.

22. Sánchez-Zamora YI, Rodriguez-Sosa M. The role of MIF in type 1 and type 2 diabetes mellitus. J Diabetes Res. 2014;2014:804519.

23. Mattana TC, Santos AS, Fukui RT, Mainardi-Novo DT, Costa VS, Santos RF, et al. CD226 rs763361 is associated with the susceptibility to type 1 diabetes and greater frequency of GAD65 autoantibody in a Brazilian cohort. Mediators Inflamm. 2014;694948.

24. Gardner A. IL6 (Interleukin 6) [Internet]. 2018 [cited 2018 Nov 3]. Available from: https://www.mygenefood.com/genes/il6/.

25. Guo B. IL-10 modulates Th17 pathogenicity during autoimmune diseases. J Clin Cell Immunol. 2016;7(2):400. 
26. Bergholdt R, Ghandil P, Johannesen J, Kristiansen OP, Kockum I, Luthman $\mathrm{H}$, et al. Genetic and functional evaluation of an interleukin-12 polymorphism (IDDM18) in families with type 1 diabetes. J Med Genet. 2004;41(4):e39.

27. Stene LC, Barriga K, Hoffman MK, Kean J, Klingensmith G, Norris $\mathrm{JM}$, et al. Normal but increasing hemoglobin A1c levels predict progression from islet autoimmunity to overt type 1 diabetes: Diabetes Autoimmunity Study in the Young (DAISY). Pediatr Diabetes. 2006;7(5):247-53.

28. Iyer A, Lanham-Newusan S, Khoja S, Al-Ghamdi M, Al Doghaither $\mathrm{H}$. Relationship between vitamin $\mathrm{D}$ receptor gene polymorphisms and type 1 diabetes mellitus in Saudi patients. Int J Pharmacol. 2017;13(8):1092-7.

29. Meller S, Di Domizio J, Voo KS, Friedrich HC, Chamilos G, Ganguly $D$, et al. $T(H) 17$ cells promote microbial killing and innate immune sensing of DNA via interleukin 26. Nature Immunol. 2015;16(9):970-9.

30. Liao W, Spolski R, Li P, Du N, West EE, Ren M, et al. Opposing actions of IL-2 and IL-21 on Thy differentiation correlate with their differential regulation of BCL6 expression. Proc Natl Acad Sci U S A. 2014;111(9):3508-13.

31. Izumi, K, Mine K, Inoue $Y$, Teshima $M$, Ogawa $S$, Kai $Y$, et al. Reduced Tyk2 gene expression in $\beta$-cells due to natural mutation determines susceptibility to virus-induced diabetes. Nat Commun. 2015;6:6748.

32. Kibirige D, Lumu W, Jones AG, Smeeth L, Hattersley AT, Nyirenda MJ. Understanding the manifestation of diabetes in sub Saharan Africa to inform therapeutic approaches and preventive strategies: a narrative review. Clin Diabetes Endocrinol. 2019;5:2.

33. National Center for Biotechnology Information, U.S. Nationa Library of Medicine. OAS1 2'-5'-oligoadenylate synthetase 1 [Homo sapiens (human)] [Internet]. Bethesda: National Center for Biotechnology Information, U.S. National Library of Medicine; 2018 [cited 2018 Jun 3]. Available from: https://www. ncbi.nlm.nih.gov/gene/4938.

34. Mehers KL, Gillespie KM. The genetic basis for type 1 diabetes. British Med Bull. 2008; 88 (1):115-29.

35. Yang $P$, Li HL, Wang CY. FUT2 nonfunctional variant: a "missing link" between genes and environment in type 1 diabetes? Diabetes. 2011;60(11):2685-7.

36. Brix L. Gene defect causes type 1 diabetes [Internet]. 2013 [cited 2018 Mar 15]. Available from: http://sciencenordic.com/genedefect-causes-type-1-diabetes.

37. Lemos NE, Dieter C, Dorfman LE, Assmann TS, Duarte GC, Canani LH, et al. The rs2292239 polymorphism in ERBB3 gene is associated with risk for type 1 diabetes mellitus in a Brazilian population. Gene. 2018;644:122-8.

38. Fukushima A, Loh K, Galic S, Fam B, Shields B, Wiede F, et al. T-cell protein tyrosine phosphatase attenuates STAT3 and insulin signaling in the liver to regulate gluconeogenesis. Diabetes. 2010;59(8):1906-14.

39. Marroquí L, Santin I, Dos Santos RS, Marselli L, Marchetti P, Eizirik DL. BACH2, a candidate risk gene for type 1 diabetes, regulates apoptosis in pancreatic $\beta$-cells via JNK1 modulation and crosstalk with the candidate gene PTPN2. Diabetes. 2014;63(7):2516-27.

40. Spolski R, Kashyap M, Robinson C, Yu Z, Leonard WJ. IL-21 signaling is critical for the development of type I diabetes in the NOD mouse. Proc Natl Acad Sci U S A. 2008;105(37):14028-33.

41. Brorsson CA, Pociot F. Shared genetic basis for type 1 diabetes, islet autoantibodies, and autoantibodies associated with other immune-mediated diseases in families with type 1 diabetes. Diabetes Care. 2015;38 Suppl 2(Suppl 2):S8-13.

42. Wallace C, Rotival M, Cooper JD, Rice CM, Yang JH, McNeill M, et al. Statistical colocalization of monocyte gene expression and genetic risk variants for type 1 diabetes. Hum Mol Genet. 2012;21(12):2815-24.

43. Fukaya M, Brorsson CA, Meyerovich K, Catrysse L, Delaroche
D, Vanzela EC, et al. A20 inhibits $\beta$-cell apoptosis by multiple mechanisms and predicts residual $\beta$-cell function in type 1 diabetes. Mol Endocrinol. 2016;30(1):48-61.

44. Wallace C, Smyth DJ, Maisuria-Armer M, Walker NM, Todd JA, Clayton DG. The imprinted DLK1-MEG3 gene region on chromosome 14932.2 alters susceptibility to type 1 diabetes. Nat Genet. 2010;42(1):68-71.

45. Dos Santos RS, Marroqui L, Velayos T, Olazagoitia-Garmendia A, Jauregi-Miguel A, Castellanos-Rubio A, et al. DEXI, a candidate gene for type 1 diabetes, modulates rat and human pancreatic beta cell inflammation via regulation of the type I IFN/STAT signalling pathway. Diabetologia. 2019;62(3):459-72.

46. Zamani F, Almasi S, Kazemi T, Esfahlan RJ, Aliparasti MR. New approaches to the immunotherapy of type 1 diabetes mellitus using interleukin-27. Adv Pharm Bull. 2015;5(Suppl 1):599-603.

47. Costes S, Vandewalle B, Tourrel-Cuzin C, Broca C, Linck N, Bertrand G, et al. Degradation of CAMP-responsive elementbinding protein by the ubiquitin-proteasome pathway contributes to glucotoxicity in beta-cells and human pancreatic islets. Diabetes. 2009;58(5):1105-15.

48. McKenzie MD, Jamieson E, Jansen ES, Scott CL, Huang DC, Bouillet $\mathrm{P}$, et al. Glucose induces pancreatic islet cell apoptosis that requires the $\mathrm{BH}$-only proteins $\mathrm{Bim}$ and Puma and multi- $\mathrm{BH}$ domain protein Bax. Diabetes. 2010;59(3):644-52.

49. Juntti-Berggren L, Refai E, Appelskog I, Andersson M, Imreh $\mathrm{G}$, Dekki N, et al. Apolipoprotein CIII promotes $\mathrm{Ca}^{2+}$-dependent beta cell death in type 1 diabetes. Proc Natl Acad Sci U S A. 2004;101(27):10090-4.

50. National Center for Biotechnology Information, U.S. National Library of Medicine. BAD BCL2 associated agonist of cell death [Homo sapiens (human)] [Internet]. Bethesda: National Center for Biotechnology Information, U.S. National Library of Medicine; 2018 [cited 2019 Mar 13]. Available from: https://www. ncbi.nlm.nih.gov/gene/572.

51. Boyd CS, Cadenas E. Nitric oxide and cell signaling pathways in mitochondrial-dependent apoptosis. Biol Chem. 2002;383(34):411-23.

52. Ishihara H, Sasaoka T, Kagawa S, Murakami S, Fukui K, Kawagishi $\mathrm{Y}$, et al. Association of the polymorphisms in the 5'-untranslated region of PTEN gene with type 2 diabetes in a Japanese population. FEBS Lett. 2003:554(3):450-4.

53. Babu, SR, Bao F, Roberts CM, Martin AK, Gowan K, Eisenbarth $G S$, et al. Caspase 7 is a positional candidate gene for IDDM 17 in a Bedouin Arab family. Ann N Y Acad Sci. 2003;1005:340-3.

54. Berchtold LA, Størling ZM, Ortis, F, Lage K, Bang-Berthelsen C, Bergholdt R, et al. Huntingtin-interacting protein 14 is a type 1 diabetes candidate protein regulating insulin secretion and beta-cell apoptosis. Proc Natl Acad Sci U S A. 2011;108(37):E6818.

55. Weaver JR, Nadler JL, Taylor-Fishwick DA. Interleukin-12 (IL-12)/ STAT4 axis is an important element for $\beta$-Cell dysfunction induced by inflammatory cytokines. PLoS One. 2015;10(11):e0142735.

56. Cameron MJ, Arreaza GA, Grattan M, Meagher C, Sharif S, Burdick MD, et al. Differential expression of CC chemokines and the $C \mathrm{CR}_{5}$ receptor in the pancreas is associated with progression to type i diabetes. J Immunol, 2000;165(2):1102-10.

57. Rorsman P, Ashcroft FM. Pancreatic $\beta$-cell electrical activity and insulin secretion: of mice and men. Physiol Rev. 98: 117-214.

58. Shoelson S, Haneda M, Blix P, Nanjo A, Sanke T, Inouye K, et al. Three mutant insulins in man. Nature. 1983;302(5908): 540-3.

59. Genetics Home Reference. HNF1A gene [Internet]. Bethesda: National Center for Biotechnology Information, U.S. National Library of Medicine; 2018 [cited 2018 Jun 26]. Available from: https://ghr.nlm.nih.gov/gene/HNF1A\#conditions.

60. Santer R, Groth S, Kinner M, Dombrowski A, Berry GT, Brodehl $J$, et al. The mutation spectrum of the facilitative glucose transporter gene SLC2A2 (GLUT2) in patients with FanconiBickel syndrome. Hum Genet. 2002;110(1):21-9. 
61. Götz J, Lim YA, Eckert A. Lessons from two prevalent amyloidoses-what amylin and $A \beta$ have in common. Front Aging Neurosci. 2013;5:38.

62. Gutiérrez GD, Bender AS, Cirulli V, Mastracci TL, Kelly SM, Tsirigos $A$, et al. Pancreatic $\beta$ cell identity requires continual repression of non- $\beta$ cell programs. Clin Invest. 2017;127(1):244-59.

63. Wen X, Yang Y. Emerging roles of GLIS3 in neonatal diabetes, type 1 and type 2 diabetes. J Mol Endocrinol. 2017;58(2):R73-85.

64. Romer Al, Singer RA, Sui L, Egli D, Sussel L. Murine perinata $\beta$-cell proliferation and the differentiation of human stem cellderived insulin-expressing cells require NEUROD1. Diabetes. 2019;68(12):2259-71.

65. Fløyel T, Brorsson C, Nielsen LB, Miani M, Bang-Berthelsen $\mathrm{CH}$, Friedrichsen $\mathrm{M}$, et al. CTSH regulates $\beta$-cell function and disease progression in newly diagnosed type 1 diabetes patients. Proc Natl Acad Sci U S A. 2014;111(28):10305-10.

66. Santos MA, Sarmento LM, Rebelo M, Doce AA, Maillard I, Dumortier $A$, et al. Notch1 engagement by delta-like-1 promotes differentiation of B lymphocytes to antibody-secreting cells. Proc Natl Acad Sci U S A. 2007;104(39):15454-9.

67. Holm LJ, Krogvold L, Hasselby JP, Kaur S, Claessens LA, Russell $\mathrm{MA}$, et al. Abnormal islet sphingolipid metabolism in type 1 diabetes. Diabetologia. 2018;61:1650-61.

68. Rachdi L, Balcazar N, Elghazi L, Barker DJ, Krits I, Kiyokawa $\mathrm{H}$, et al. Differential effects of $\mathrm{p} 27$ in regulation of $\beta$-cell mass during development, neonatal period, and adult life. Diabetes. 2006;55(12):3520-8.

69. Kulkarni RN. New insights into the roles of insulin/IGF-I in the development and maintenance of beta-cell mass. Rev Endocr Metab Disord. 2005;6(3):199-210.

70. Dendrou CA, Wicker LS. The IL-2/CD25 pathway determines susceptibility to T1D in humans and NOD mice. J Clin Immunol.
2008;28(60):685-96.

71. Genetics Home Reference. Histocompatibility complex [Intenet]. Bethesda: National Center for Biotechnology Information, U.S. National Library of Medicine; 2018 [cited 2018 Jun 26]. Available from: https://ghr.nlm.nih.gov/primer/ genefamily/hla.

72. Notkins AL. Immunologic and genetic factors in type 1 diabetes. J Biol Chem. 2002:277(46):43545-8.

73. National Center for Biotechnology Information, U.S. National Library of Medicine. INS insulin [Homo sapiens (human)] [Internet]. Bethesda: National Center for Biotechnology Information, U.S. National Library of Medicine; 2018 [cited 2018 Jun 27]. Available from: https://www.ncbi.nlm.nih.gov/ gene/3630\#gene-expression.

74. Concannon P, Erlich HA, Julier C, Morahan G, Nerup J, Pociot F, et al. Type 1 diabetes: evidence for susceptibility loci from four genome-wide linkage scans in 1,435 multiplex families. Diabetes. 2005;54(10):2995-3001.

75. Kantárová D, Buc M. Genetic susceptibility to type 1 diabetes mellitus in humans. Physiol Res. 2007;56(3):255-66.

76. Sharp RC, Abdulrahim M, Naser ES, Naser SA. Genetic variations of PTPN2 and PTPN22: role in the pathogenesis of type 1 diabetes and Crohn's disease. Front Cell Infect Microbiol. 2015;5:95.

77. Steck AK, Rewers MJ. Genetics of type 1 diabetes. Clin Chem. 2011;57(2):176-85.

78. Bingley PJ, Bonifacio E, Ziegler AG, Schatz DA, Atkinson MA, Eisenbarth GS, et al. Proposed guidelines on screening for risk of type 1 diabetes. Diabetes Care. 2001;24(2):398.

79. Schroder K, Hertzog PJ, Ravasi T, Hume DA. Interferon-gamma: an overview of signals, mechanisms and functions. J Leukoc Biol. 2004;75(2):163-89. 